\title{
PENCIPTAAN BUDAYA RELIGIUS PERGURUAN TINGGI ISLAM (Berkaca Nilai Religius UIN Maulana Malik Ibrahim Malang)
}

\author{
Amru Almu'tasim \\ STIT Uluwiyah Mojokerto \\ e-mail: amru.dosen@yahoo.com
}

\begin{abstract}
During these universities only produce graduates who only have a certain skill, while they do not have personal integrity as a member of the family, community, and religious citizens. This situation will greatly affect the education system in universities. Where the College as an organization of higher education is a means of cooperation group of people (Higher Education and Society) to achieve the desired objectives. Achievement of the goal Universities, both in quality and quantity depends on the people who gathered at the agency. if the increase is not accompanied by planting intellectual Islamic values are embodied in building religious culture in the Universities, the national education goals will not be achieved well.
\end{abstract}

Keywords: Religious, Culture, Higher Education

\begin{abstract}
Abstrak: Selama ini universitas hanya menghasilkan lulusan yang hanya memiliki keahlian tertentu, sementara itu mereka tidak memiliki integritas pribadi sebagai anggota keluarga, komunitas, dan warga Negara yang beragama. Situasi ini akan sangat mempengaruhi sistem pendidikan di perguruan tinggi. Dimana kampus sebagai organisasi pendidikan tinggi merupakan sarana kelompok kerja sama orang (Pendidikan Tinggi dan Masyarakat) untuk mencapai tujuan yang diinginkan. Pencapaian dari tujuan Universitas, baik dalam kualitas dan kuantitas tergantung pada orang-orang yang berkumpul di lembaga tersebut. jika pertumbuhan tersebut tidak disertai dengan menanam nilai-nilai Islam intelektual yang diwujudkan dalam membangun budaya agama di Universitas, maka tujuan pendidikan nasional tidak akan tercapai dengan baik.
\end{abstract}

Kata-Kata kunci: Agama, Budaya, Pendidikan Tinggi

\section{Pendahuluan}

Pendidikan merupakan salah satu investasi yang sangat berharga bagi Masyarakat. Pendidikan yang dapat menjanjikan 
terhadap Masyarakat berarti pendidikan yang dapat mengantarkan perubahan yang sangat berarti dalam Masyarakat tersebut. Selanjutnya, perubahan model pendidikan yang beraneka ragam dalam mewujudkan urgensinya tidak dapat dilepas pisahkan dengan tuntutan situasi dan kondisi Masyarakat (Asrori, 2008: 31).

Dalam UU No. 20 / 2003 Tentang Sisdiknas Pasal 1 ayat 1 dinyatakan bahwa pendidikan adalah usaha sadar dan terencana untuk mewujudkan suasana belajar dan pembelajaran agar peserta didik secara aktif mengembangkan potensi dirinya untuk memiliki kekuatan spiritual keagamaan, pengendalian diri, kepribadian, kecerdasan, akhlak mulia serta keterampilan yang diperlukan untuk dirinya, masyarakat, bangsa dan Negara. Selanjutnya pasal 1 ayat 2 dinyatakan bahwa pendidikan nasional adalah pendidikan yang berdasarkan pancasila dan Undang-Undang Dasar Negara Republik Indonesia Tahun 1945 berakar pada Nilai-Nilai Agama, kebudayaan nasional Indonesia dan tanggap terhadap tuntutan perubahan zaman.

Pendidikan Agama Islam (PAI) baik pada jenjang pendidikan dasar maupun menengah antara lain bertujuan untuk mewujudkan manusia Indonesia yang taat beragama dan berakhlak mulia, yaitu manusia yang berpengetahuan, rajin beribadah, cerdas, produktif, jujur, adil, etis, berdisiplin, bertoleransi (tasamuh) menjaga keharmonisan, secara personal dan social serta Mengembangkan Budaya Agama dalam komunitas Perguruan Tinggi (Permen Diknas, No: 22 tanggal 23 Mei 2006 tentang Standar isi dalam standar kompetensi dan kompetensi dasar mata pelajaran PAI. Dengan demikian upaya pengembangan Pendidikan Agama sebagai Budaya Perguruan Tinggi telah memperoleh legalitas yang kuat.

Pendidikan Agama khususnya Islam, sebenarnya memiliki kawasan yang begitu luas, dengan target obsesi agar melalui pendidikan ini para mahasiswa mampu memahami, menghayati dan menerapkan ajaran-ajaran Islam yang termuat dalam kitab suci Alqur'an dan Sunnah Rasul. Kedua sumber ajaran ini sebagai mana kita ketahui memuat segala aspek kehidupan, baik aspek ritual, intlektual, sosio maupun lainnya. Sasaran yang ingin dicapai dan dikembangkan meliputi aspek hati nurani agar memiliki kehalusan budi (Ahlakul 
karimah) daya nalar dan pikir agar anak cerdas dan memiliki keterampilan yang tinggi (Suprayogo, 1999: 25).

Dewasa ini bangsa Indonesia sedang menghadapi krisis mental yang multidimensional. Dari hasil kajian berbagai disiplin dan pendekatan, tampaknya ada kesamaan pandangan bahwa segala macam krisis itu berpangkal dari krisis akhlak atau moral. Krisis ini, secara langsung atau tidak, berhubungan dengan persoalan Perguruan Tinggi atau pendidikan (Muhaimin, 2009: 18). Banyak mahasiswa dan pelajar sekarang mudah terpengaruh oleh budaya asing, mudah terprovokasi, cepat marah, pergaulan bebas, bahkan banyak dari mereka tidak lagi menaruh hormat terhadap guru-gurunya, bahkan tidak hormat terhadap orang tua. Hal ini merupakan gambaran anak bangsa yang mulai terancam keutuhan pribadinya (Alim, 2006: 1).

Melihat kenyataan di atas, maka sangatlah beralasan, apabila kemudian ada kritik dari masyarakat bahwa selama ini Perguruan Tinggi hanya menghasilkan lulusan yang hanya memiliki keahlian tertentu, sementara mereka tidak memiliki integritas kepribadian sebagai anggota keluarga, masyarakat, dan warga Negara yang beragama. Kondisi demikian tentunya sangat berpengaruh pada sistim pendidikan di Perguruan Tinggi. Dimana Perguruan Tinggi sebagai suatu organisasi pendidikan tinggi merupakan wadah kerjasama sekelompok orang (Perguruan Tinggi dan Masyarakat) untuk mencapai tujuan yang diinginkan. Pencapaian tujuan Perguruan Tinggi, baik kualitas maupun kwantitas sangat tergantung pada orang-orang yang terhimpun di lembaga tersebut. jika peningkatan intelektual tidak dibarengi dengan penanaman nilai-nilai Islam yang diwujudkan dalam membangun budaya religius di Perguruan Tinggi, maka tujuan pendidikan nasional tidak akan tercapai dengan baik.

\section{Budaya Religius (Religious Culture)}

Penciptaan suasana atau budaya religius berarti menciptakan suasana atau iklim kehidupan keagamaan. Dalam suasana atau iklim kehidupan keagamaan Islam yang dampaknya ialah berkembangnya suatu pandangan hidup yang bernapaskan atau dijiwai oleh ajaran dan nilai-nilai agama Islam, yang diwujudkan dalam sikap hidup serta 
keterampilan hidup oleh para warga Perguruan Tinggi. Dalam arti kata, penciptaan suasana religius ini dilakukan dengan cara pengamalan, ajakan (persuasif) dan pembiasaan-pembiasaan sikap agamis baik secara vertikal (habluminallah) maupun horizontal (habluminannas) dalam lingkungan Perguruan Tinggi. Melalui penciptaan ini, mahasiswa akan disuguhkan dengan keteladanan kepala Perguruan Tinggi dan para guru dalam mengamalkan nilai-nilai keimanan, dan salah satunya yang paling penting adalah menjadikan keteladanan itu sebagai dorongan untuk meniru dan mempraktikkannya baik di dalam Perguruan Tinggi atau di luar Perguruan Tinggi. Sikap mahasiswa sedikit banyak pasti akan terpengaruh oleh lingkungan di sekitarnya (Mulyasa, 2005: 32).

Istilah budaya mula-mula datang dari disiplin ilmu antropologi sosial. Apa yang tercakup dalam definisi budaya sangatlah luas. Istilah budaya dapat diartikan sebagai totalitas pola perilaku, kesenian, kepercayaan, kelembagaan dan semua produk lain dari karya dan pemikiran manusia yang mencirikan kondisi suatu masyarakat atau penduduk yang ditransmisikan bersama (Kotter, 1992: 4).

Dalam kamus besar bahasa Indonesia, budaya (cultural) diartikan: Pikiran, adat istiadat, sesuatu yang berkembang, sesuatu yang menjadi kebiasaan yang sukar diubah. Dalam pemakaian seharihari, orang biasanya mensinonimkan pengertian budaya dengan tradisi. Dalam hal ini, tradisi diartikan sebagai ide-ide umum, sikap dan kebiasaan dari masyarakat yang nampak dari perilaku sehari-hari yang menjadi kebiasaan dari kelompok dalam masyarakat tersebut (Indrafachrudi, 1994: 18).

Pendapat Koentjaraningrat mengelompokkan aspek-aspek budaya berdasarkan dimensi wujudnya, yaitu: 1) komplek gugusan atau ide seperti pikiran, pengetahuan, nilai, keyakinan, norma dan sikap, 2) komplek aktifitas seperti pola komunikasi, tari-tarian, ucapan adat. 3) material hasil benda seperti seni, peralatan dan lain sebagainya (Koentjaraningrat, 1969: 17). Sedang menurut Robert K. Marton diantara segenap unsur-unsur budaya terdapat unsur yang terpenting yaitu kerangka aspirasi tersebut, dalam artian ada nilai budaya yang merupakan konsepsi abstrak yang hidup di dalam alam pikiran (Femandes, 1990: 28). 
Sedangkan pengertian religius (agama). Dalam bahasa Arab dikenal dengan kata al-din dan al-milah. Kata al-din sendiri mengandung berbagai arti. Ia bisa berarti al-mulk (kerajaan), alkhidmat (pelayanan), al-izz (kejayaan), al-dzull (kehinaan), al-ikrah (pemaksaan), al-ihsan (kebijakan), al-adat (kebiasaan), al-ibadat (pengabdian), al-qahr wa al-sulthan (kekuasaan dan pemerintahan), altadzallul wa al-khudu (tunduk dan patuh), al-tha at (taat), al-islam altaukid (penyerahan dan mengesakan Tuhan) (Kahmad, 2002: 13).

Menurut Nurkholis Majid, agama bukanlah sekedar tindakantindakan ritual seperti sholat dan membaca Al-qur'an serta membaca do'a. Agama lebih dari itu, yaitu keseluruhan tingkah laku manusia yang terpuji dalam kehidupan sehari-hari, yang dilakukan demi memperoleh ridho Allah. Dengan demikian maka agama adalah, meliputi keseluruhan tingkah laku manusia dalam hidup ini, dengan tingkah laku itu membentuk keutuhan manusia berbudi luhur atas dasar percaya atau iman kepada Allah dan tanggung jawab di hari kemudian (Madjid, 1997: 124).

Dari beberapa pengertian diatas, bisa disimpulkan bahwa budaya religius adalah cara berfikir dan cara bertindak warga Perguruan Tinggi yang didasarkan atas nilai-nilai religius (keberagamaan). Religius menurut Islam adalah menjalankan ajaran agama secara menyeluruh (kaffah) (Muhaimin, 2001: 294).

\section{Konsep Budaya Religus di Perguruan Tinggi}

Konsep Islam tentang budaya agama dapat dipahami dari doktrin keagamaan. Dalam Islam seseorang diperintahkan untuk beragama secara kaffah, hal ini dijelaskan dalam Al-qur'an surat Al baqarah ayat 208 :

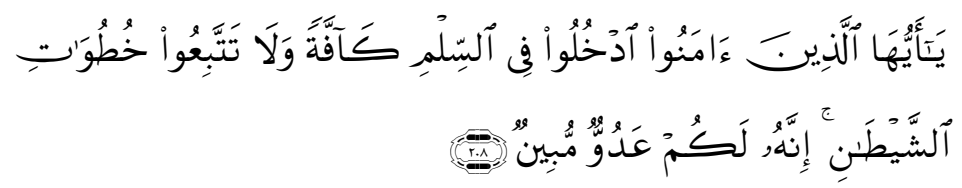

Hai orang-orang yang beriman, masuklah kamu ke dalam Islam keseluruhan, dan janganlah kamu turut langkahlangkah syaitan. Sesungguhnya syaitan itu musuh yang nyata bagimu. 
Setiap muslim baik dalam berfikir, bersikap maupun bertindak, diperintahkan untuk selalu sesuai dengan ajaran islam. Dalam melakukan aktifitas ekonomi, sosial, politik atau aktifitas lainnya seorang muslim diperintahkan untuk melakukannya dalam rangka beribadah kepada Allah, dimanapun dan dalam keadaan apapun setiap muslim hendaknya berpedoman pada Al-qur'an dan as-sunnah.

Keberagamaan seseorang bisa diwujudkan dalam berbagai sisi kehidupan, Aktifitas agama bukan saja terjadi ketika seseorang melakukan prilaku ritual (beribadah), tetapi juga ketika melakukan kegiatan lain yang didorong oleh kekuatan supranatural. Bukan hanya berkaitan dengan aktifitas yang tampak dan dapat dilihat dengan mata, tetapi juga aktifitas yang tidak tampak dan terjadi dalam hati seseorang (Ancok, 1995: 76). Karena itu keberagaman seseorang akan meliputi berbagai macam sisi atau dimensi. Dimensi religiusitas menurut Glock dan Strak dalam Widiyanto ada lima demensi religiusitas dijelaskan sebagai berikut:

1. Religious practice (the ritualistic dimension). Tingkatan sejauh mana seseorang mengerjakan kewajiban ritual di dalam agamanya, seperti shalat, zakat, puasa dan sebaginya.

2. Religious belief (the ideological dimension). Sejauh mana orang menerima hal-hal dogmatik di dalam ajaran agamanya. Misalnya kepercayaan tentang adanya Tuhan, Malaikat, Kitab-kitab, Nabi dan Rasul, hari kiamat, surga, neraka dan yang lain-lain yang bersifat dogmatik.

3. Religious knowledge (the intellectual dimension). Sejauhmana seseorang mengetahui tentang ajaran agamanya. Hal ini berhubungan dengan aktifitas seseorang untuk mengetahui ajaranajaran dalam agamanya.

4. Religious feeling (the experiental dimension). Dimensi yang terdiri dari perasaan-perasaan dan pengalaman-pengalaman keagamaan yang pernah dirasakan dan dialami. Misalnya seseorang merasa dekat dengan Tuhan, seseorang merasa takut berbuat dosa, seseorang merasa doanya dikabulkan Tuhan, dan sebaginaya.

5. Religious effect (the consequential dimension). Dimensi yang mengukur sejauhmana perilaku seseorang dimotivasikan oleh 
ajaran agamanya di dalam kehidupannya. Misalnya mengikuti kegiatan konversasi lingkungan alam dan lain-lain (Widiyanta, 2002: 20).

Adapun strategi untuk membudayakan nilai-nilai religius di Perguruan Tinggi dapat dilakukan melalui:

1. Power Strategy: yakni strategi budaya religius di Perguruan Tinggi dengan menggunakan kekuasaan atau melalui people`s power, dalam hal ini peran kepala Perguruan Tinggi dengan segala kekuasaannya sangat dominan dalam melakukan perubahan.

2. Persuasive Power: yang dijalankan lewat pembentukan opini dan pandangan masyarakat atau warga Perguruan Tinggi.

3. Normative Re-Educative: Norma adalah aturan yang berlaku di masyarakat lewat education. Normative digandengkan dengan reeducative (pendidikan ulang) untuk menanamkan dan mengganti paradigma berfikir masyarakat Perguruan Tinggi yang lama dengan yang baru (Muhaimin, 2009: 328).

Pada strategi pertama dilaksanakan melalui pendekatan perintah dan larangan atau reward and punishment. Sedangkan pada strategi kedua dan ketiga dilaksanakan melalui pembiasaan, keteladanan, kemitraan, internalisasi dan pendekatan persuasive atau mengajak kepada warganya dengan cara halus, dengan memberikan alasan dan prospek baik yang bisa menyakinkan mereka. Konsep budaya religius juga dapat dilihat dari tiga hal sebagai berikut:

1. Budaya Religius Sebagai Orientasi Moral

Moral adalah keterikatan spiritual pada norma-norma yang telah diterapkan, baik yang bersumber pada ajaran agama, budaya masyarakat atau berasal dari tradisi berfikir secara ilmiyah. Keterikatan spiritual tersebut akan mempengaruhi keterikatan sikapnya terhadap nilai-nilai kehidupan (norma) yang akan menjadi pijakan utama dalam menetapkan suatu pilihan, pengembangan perasaan dan menetapkan tindakan.

Keterikatan pada norma-norma agama akan membentuk sikap tertentu dalam menyikapi segala persoalan. Moral yang dilaksanakan atas pijakan agama, maka pertimbangan-pertimbangan moralnya akan lebih berorientasi pada kewajiban beragama. Sedangkan sumbersumber moral lainnya hanya dibenarkan manakala dianggap sesuai 
dengan ajaran agama. Segala tindakan moral yang didasari ketentuan agama muncul karena rasa tanggungjawab kepada Tuhan. Segala tindakan yang diambil dirasakan sebagai keharusan robbani. Sedangkan motif memilih tindakan tersebut semata-mata karena ingin mendapat keridhaan Tuhan. Oleh karena itu internal control pada moral yang berorientasi pada agama (orientasi moral religius) akan lebih jauh lebih dominan untuk melakukan suatu tindakan moral daripada eksternal control. Inilah yang membedakan orientasi moral religius dengan orientasi moral yang hanya sekedar didasarkan atas hasil pemikiran manusia.

Budaya religius yang terbentuk dari keterikatan yang kuat pada norma-norma yang diterapkan oleh agama akan menjadikan seorang dapat mengukur kebenaran suatu hal dari sudut pandangan agama. Sebagai orientasi moral, budaya religius bermakna keterikatan spiritual pada norma-norma ajaran agama yang akan menjadi acuan pertama ukuran moral (Alim, 2006: 9 - 10).

2. Budaya Religius Sebagai Internalisasi Nilai Agama

Internalisasi nilai agama ialah proses memasukkan nilai agama secara penuh kedalam hati, sehingga ruh dan jiwa bergerak berdasarkan ajaran agama. Internalisasi nilai agama terjadi melalui pemahaman ajaran agama secara utuh dan diteruskan dengan kesadaran akan pentingnya ajaran agama, serta ditemukannya posibilitas untuk merealisasikannya dalam kehidupan nyata.

Dari segi isi, agama terdiri dari seperangkat ajaran yang merupakan perangkat nilai-nilai kehidupan yang harus dijadikan barometer para pemeluknya dalam menentukan pilihan tindakan dalam kehidupannya. Nilai-nilai ini secara popular disebut dengan nilai agama. Oleh sebab itu nilai-nilai agama merupakan seperangkat standar kebenaran dan kebaikan.

Nilai-nilai agama adalah nilai luhur yang ditransfer dan diadopsi kedalam diri. Oleh karena itu seberapa banyak dan seberapa jauh nilainilai agama bisa mempengaruhi dan membentuk sikap serta perilaku seseorang sangat tergantung dari seberapa dalam nilai-nilai agama terinternalisasikan dalam diri seseorang. , kepribadian dan budaya religiusnya akan muncul dan terbentuk. Jika budaya religius sudah muncul dan terbentuk, maka nilai-nilai agama akan menjadi pusat nilai 
dalam menyikapi segala sesuatu dalam kehidupan. Allah berfirman dalam Al Qur'an Surat Al Maidah ayat 48:

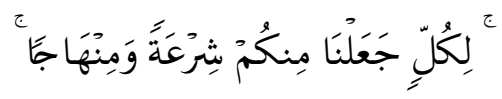

Untuk tiap-tiap umat diantara kamu, Kami berikan aturan dan jalan yang terang.

Ayat ini mempunyai makna bahwa manusia memiliki kebudayaan dunia yang berkaitan tentang tata cara hidup bahkan mulai dari wahyu yang diturunkan Allah SWT pada mereka (tiap-tiap umat) hingga masa pelbagai penyimpangan aqidah. Karena itulah Allah menyuruh untuk kembali kepada jalan kebaikan yang dituntun-Nya. Pelajaran penitng dari ayat ini adalah tentang nilai kearifan. Dalam konteks budaya modern sering disebut dengan kearifan universal dan kearifan lokal (local wisdom).

Untuk itulah berbagai aspek yang berkenan dengan agamanya itu perlu dikaji secara seksama dan mendalam, sehingga dapat membuahkan pemahaman keagamaan yang komprehensip. Dengan kwalitas pemahaman yang komprehensip, seseorang akan terbimbing pola pikir, sikap dan segala tindakan yang diambilnya (Alim, 2006: 10 11).

3. Budaya Religius Sebagai Etos Kerja dan Keterampilan Sosial

Seperangkat ajaran dalam agama bertujuan membimbing, mendorong untuk berbuat dan memilih tindakan tertentu. Lebih penting dari itu agama berperan sebagai sumber etos kerja, bagi seseorang pemeluk agama, etos kerja muncul dari dorongan sikap yang terbentuk oleh nilai-nilai agama. Sebagai etos kerja, budaya religius memberikan dorongan kepada seseorang dalam mencari makna religius bagi tindakan yang pilihannya, Demikian, tindakan dan perbuatan yang dilakukannya tindakan lagi dirasakan sebagai beban, melainkan sebagai sumber kepuasan batiniyah.

Kesanggupan seseorang menampilkan nilai-nilai agama dalam kehidupannya sebagai suatu keterampilan sosial sangat tergantung pada kuat lemahnya pemahaman agama yang ada dalam jiwanya. Pemahaman agama tersebut tampil dalam bentuk tindakan dan 
perilaku terhadap lingkungan selaras dengan apa yang diperintahkan oleh ajaran agama. Bagi yang memiliki budaya religius, agama secara konsekwen tampil dalam bentuk tindakan-tindakan yang mendukung terbentuknya tatanan sosial yang harmonis.

Ada beberapa hal yang dapat dijadikan indikator budaya religius seseorang, yakni; 1) komitmen terhadap perintah dan larangan agama, 2) bersemangat mengkaji ajaran agama, 3) aktif dalam kegiatan agama, 4) menghargai simbol-simbol agama, 5) akrab dengan kitab suci, 6) mempergunakan pendekatan agama dalam membentuk pilihan, 7) ajaran agama dijadikan sebagai sumber perwujudan ide (Alim, 2006: 11 - 12). Allah berfirman dalam Al-Qur'an :

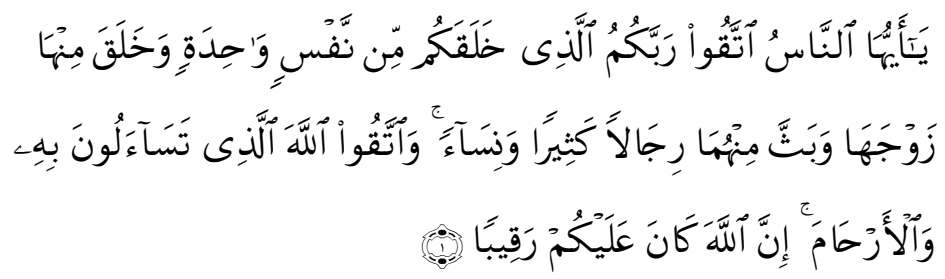

"Hai sekalian manusia, bertakwalah kepada Tuhan-mu yang telah menciptakan kamu dari seorang diri, dan dari padanya Allah menciptakan isterinya; dan dari pada keduanya Allah memperkembang biakkan laki-laki dan perempuan yang banyak. dan bertakwalah kepada Allah yang dengan (mempergunakan) nama-Nya kamu saling meminta satu sama lain, dan (peliharalah) hubungan silaturrahim. Sesungguhnya Allah selalu menjaga dan mengawasi kamu."

Dari beberapa penjelasan di atas dapat disimpulkan bahwa melaksanakan budaya religius adalah suatu usaha untuk menumbuhkembangkan beberapa pokok masalah dalam kehidupan beragama yang datangnya dari Allah SWT terdiri dari tiga unsur pokok yaitu aqidah, ibadah, dan akhlak yang menjadi pedoman perilaku sesuai dengan aturan-aturan illahi untuk mencapai kesejahteraan serta kebahagiaan hidup di dunia dan akherat. Agama menjadi sumber paling luhur bagi manusia sebab yang digarap oleh agama ialah masalah mendasar untuk kehidupan manusia yaitu perilaku (akhlak). 
Kemudian segi ini dihidupkannya dengan kekuatan ruh tauhid atau aqidah dan ibadah kepada Tuhan.

\section{Terbentuknya Budaya Religius di Perguruan Tinggi}

Dalam menciptakan budaya religius di Perguruan Tinggi, dapat mengacu kepada beberapa model yang ditawarkan. Model adalah sesuatu yang dianggap benar, tetapi bersifat kondisional. Karena itu penciptaan suasana religius sangat dipengaruhi oleh situasi dan kondisi tempat model itu akan diterapkan beserta penerapan nilainilai yang mendasarinya. Menurut Muhaimin, ada 4 model pengembangan budaya agama dikomunitas Perguruan Tinggi yaitu :

1. Model Struktural. Pengembangan budaya agama dengan model ini disemangati oleh adanya peraturan-peraturan, pembangunan kesan, baik dari dunia luar maupun dari kepemimpinan atau kebijakan suatu lembaga pendidikan atau suatu organisasi. Model ini biasanya bersifat tof down yakni kegiatan keagamaan yang dibuat atas prakarsa atau instruksi dari pejabat atau pimpinan atasan.

2. Model Formal. Pengembangan budaya agama model ini didasari atas pemahaman bahwa pendidikan agama adalah upaya manusia untuk mengembangkan dan mengerjakan masalah-masalah kehidupan akhirat atau kehidupan rohani saja, sehingga pendidikan agama dihadapkan dengan pendidikan non keagamaan, pendidikan keislaman dengan pendididkan non keislaman, pendidikan Kristen dengan non Kristen demikian seterusnya. Model pengembangan budaya agama ini, lebih berimplikasi terhadap pengembangan pendidikan agama yang lebih berorientasi pada keakhiratan, sedangkan masalah dunia dianggap tidak penting, serta menekankan pada pendalaman ilmu-ilmu keagamaan yang merupakan jalan pintas untuk menuju kebahagiaan akhirat. Sementara sains (ilmu-ilmu pengetahuan) dianggap terpisah dari ilmu-ilmu agama.

3. Model Mekanik. Pengembangan budaya agama dengan model ini adalah yang didasari oleh pemahaman bahwa kehidupan terdiri dari beberapa aspek, dan pendidikan dipandang sebagai 
penanaman dan pengembangan seperangkat nilai kehidupan yang masing-masing bergerak dan menjalankan fungsinya. Masingmasing gerak bagaikan sebuah mesin yang terdiri atas beberapa komponen atau elemen-elemen, yang masing-masing menjalankan fungsinya sendiri-sendiri, dan antara satu dengan yang lainnya bisa saling berkonsultasi atau tidak. Model mekanik tersebut berimplikasi terhadap pengembangan pendidikan agama islam yang lebih menonjolkan fungsi moral dan spiritual atau dimensi afektif daripada kognitif dan psikomotorik. Artinya dimensi Kognitif dan psikomotorik dapat diarahkan untuk pembinaan afektif (moral dan spiritual), yang berbeda dengan pelajaran lainnya kegiatan dan kajian-kajian keagamaan hanya untuk pendalaman agama dan kegiatan spiritual keagamaan)

4. Model Organik. Pengembangan budaya agama dengan model ini, yaitu pengembangan budaya agama yang disemangati oleh adanya pandangan bahwa pendidikan agama adalah kesatuan atau sebagai system (yang terdiri atas komponen-komponen yang rumit) yang berusaha mengembangkan pandangan atau semangat hidup agamis, yang dimanifestasikan dalam sikap hidup dan keterampilan hidup yang religious (Muhaimin, 2001: 305 - 307). Model pengembangan budaya agama organic tersebut berimplikasi terhadap pengembangan pendidikan agama yang dibangun dari fundamental values (lingkungan) yang tertuang dan terkandung dalam Al-qur'an dan Al-sunnah shahihah sebagai sumber pokok kemudian bersedia mau menerima konstribusi pemikiran dari para ahli serta mempertimbangkan konteks historisnya. Karena itu, nilai ahli Ilahi/ agama / wahyu didudukan sebagai sumber konsultasi yang bijak.

Dalam kaitanya dengan pelaksanaan budaya religius di Perguruan Tinggi, ciri-ciri Perguruan Tinggi religius, cirinya Perguruan Tinggi memiliki kondisi yang konduktif dalam artian bernuansa keagamaan adalah:

1. Kepala Perguruan Tinggi harus dapat menjadi modal atau suritauladan bagi para pembantunya.

2. Kepala Perguruan Tinggi dan guru agama bersama-sama mengadakan kegiatan bernuansa religius seperti kegiatan, BTA, 
shalat Jumat di Perguruan Tinggi, pesantren ramadhan, PHBI dan yang berkaitan dengan nilai-nilai keagamaan.

3. Dalam pelaksanaan budaya religius hendaknya mengadakan kegiatan mempererat tali ukhuwah Islamiyah dengan organisasi lain, tadabur alam, dengan demikian akan tercipta suasana yang kondusif penuh keakraban, perdamaian dan kebersamaan.

4. Menjadikan pendidikan pada dirinya sebagai tauladan yang baik dengan mengontrol diri dari perbuatan jelek

5. Memiliki fasilitas keagamaan yang memadahi untuk kegiatan keagamaan seperti masjid/ musholla, tempat wudlu dan lain sebagainya (Roibin, 2003: 13).

Pelaksanaan budaya religius di Perguruan Tinggi mempunyai landasan yang kokoh baik secara normative religius maupun konstitusinal, sehingga tidak ada alasan bagi Perguruan Tinggi untuk mengelak dari upaya tersebut (Muhaimin, 2009: 305). Oleh karena itu, penyelenggaraan pendidikan agama yang diwujudkan dalam pelaksanaan budaya religius di berbagai jenjang pendidikan, patut untuk dilaksanakan. Karena dengan tertanamnya nilai-nilai agama pada diri mahasiswa maka akan memperkokoh imannya, dan aplikasi nilai-nilai keIslaman tersebut dapat tercipta dari lingkungan Perguruan Tingginya. Untuk itu pelaksanaan budaya religius sangat penting dan akan mempengaruhi sikap, sifat dan tindakan secara tidak langsung.

\section{Kesimpulan}

1. Budaya religius adalah cara berfikir dan cara bertindak warga Perguruan Tinggi yang didasarkan atas nilai-nilai religius (keberagamaan). Religius menurut Islam adalah menjalankan ajaran agama secara menyeluruh (kaffah).

2. Dalam konsep budaya religius, terdapat beberapa hal yang penting, dilihat dari segi dimensi religiusitas, segi strategi, dan segi konsep budaya itu sendiri. Segi dimensi religiusitas: Religious practice (the ritualistic dimension), Religious belief (the ideological dimension), Religious knowledge (the intellectual dimension), Religious feeling (the experiental dimension) dan Religious effect (the consequential dimension). Dari Segi strategi: power Strategy, Persuasive Power dan 
Normative Re-Educative. Dari segi konsep budaya: Budaya Religius Sebagai Orientasi Moral, Budaya Religius Sebagai Internalisasi Nilai Agama dan Budaya Religius Sebagai Etos Kerja dan Ketrampilan Sosial

3. Terbentuknya Budaya religius di Perguruan Tinggi. Dalam menciptakan budaya religius di Perguruan Tinggi, dapat mengacu kepada beberapa model yang ditawarkan. ada 4 model pengembangan budaya agama dikomunitas Perguruan Tinggi yaitu :Model Struktural, Model Formal, Model Mekanik dan Model Organik 


\section{DAFTAR PUSTAKA}

Asrori, Muhammad. 2008. Dinamika Pendidikan Islam Di Indonesia, Jurnal El-Harokah. Malang: UIN Press

Alim, Muhammad , 2006. Pendidikan Agama Islam: Upaya Pembentukan Pemikiran dan Keppribadian Muslim, Bandung: PT Remaja Rosda Karya.

Dadang Kahmad, 2002, Sosilogi Agama, Bandung : PT. Remaja Rosdakarya.

Departemen Pendidikan dan Kebudayaan, 1991, Kamus Besar Bahasa Indonesia, Jakarta : PT. Balai Pustaka.

Djmaluddin A, 1995, Psikologi Islam, Solusi Islam atas Problem-Problem Psikologi, Cet II, Yogyakarta : Pustaka Pelajar.

Fernandes, S.O, 1990, Citra Manusia Budaya Timur dan Barat, Nusa Indah, NTT.

J.P. Kotter \& J.L. Hesket, 1992, Dampak Budaya Perusahaan Terhadap Kinerja. Terjemahan oleh Benyamin Molan, Jakarta : Prenhallindo.

Koentjaraningrat, 1969, Rintangan-rintangan Mental Dalam Pembangunan Ekonomi di Indonesia, Jakarta : Lembaga Riset Kebudayaan Nasional Seni No. 2.

Muhaimin. 2009, Pengembangan Kurikulum Pendidikan Agama Islam Di Perguruan Tinggi, Madrasah, dan Perguruan Tinggi. Jakarta : PT RajaGrapindo Persada

------------, 2001, Paradigma Pendidikan Islam : Upaya Mengefektifkan Pendidikan Agama Islam di Perguruan Tinggi, Bandung : PT. Remaja Rosdakarya

2009, Rekontruksi Pendidikan Islam, Dari Paradigma Pengembangan, Manajemen Kelembagaan, Kurikulum hingga Strategi Pembelajaran, PT. RajaGrafindo Persada, Jakarta 
-, 2001, Paradigma Pendidikan Islam : Upaya Mengefektifkan Pendidikan Agama Islam di Perguruan Tinggi, Bandung : PT. Remaja Rosdakarya.

----------, 2009, Pengembangan Kurikulum dan Pembelajaran : Upaya Reaktua-lisasi Pendidikan Islam. Malang : LKP21

Mulyasa. 2005. Pedoman Manajemen Berbasis Madrasah, Cet. II; Jakarta: Departemen Agama RI

Nurcholis Madjid, 1997, Masyarakat Religius, Jakarta : Paramadina.

Permen Diknas No 22 tanggal 23 Mei 2006

Roibin, 2003, Menuju Pendidikan Berbasis Kerukunan, Majalah ElHarakah.

Soekarta Indrafchrudi, 1994. Bagaimana Mengakraban Perguruan Tinggi Dengan Orang tua Murid dan Masyarakat, Malang : IKIP.

Suprayogo, Imam. 1999. Reformasi Visi dan Misi Pendidikan Islam. Malang: STAIN Press

Undang-Undang RI Nomor 20 Tahun 2003 Tentang Sisdiknas \& Peraturan Pemerintah RI Nomor 47 Tahun 2008 Tentang Wajib Belajar, ( Bandung: Citra Umbara, 2008 )

Widiyanta, Ari. 2002. Sikap Terhadap Lingkungan alam (Tinjauan Islam Dalam Menyelesaikan Masalah Lingkungan), Makalah Psikologi : fakultas Kedokteran/ Program Studi Psikologi Universitas Sumatera Utara 